\title{
REFLECTION
}

\section{Suffering, Meaning, and Healing: Challenges of Contemporary Medicine}

Thomas R. Egnew, EdD, LICSW

Tacoma Family Medicine, Tacoma $;$ and Department of Family Medicine, University of Washington School of Medicine, Seattle, Washington
Conflicts of interest: none reported

\section{CORRESPONDING AUTHOR}

Thomas R. Egnew, EdD, LICSW

Tacoma Family Medicine

521 Martin Luther King Jr Way

Tacoma, WA 98405-4238

tom.egnew@multicare.org

\begin{abstract}
This essay explores the thesis that changes in contemporary society have transformed the work of doctoring and challenge doctors to be physician-healers. Medical advances in the prevention and management of acute disease have wrought a growing population of chronically ill patients whose care obliges physicians to become holistic healers. Holistic healing involves the transcendence of suffering. Suffering arises from perceptions of a threat to the integrity of personhood, relates to the meaning patients ascribe to their illness experience, and is conveyed as an intensely personal narrative. Physician-healers use the power of the doctor-patient relationship to help patients discover or create new illness narratives with fresh meanings that reconnect them to the world and to others and thereby transcend suffering and experience healing. Physician-healers equipped with the attitudes, skills, and knowledge to assist patients to transcend suffering are indispensable if contemporary medicine is to maintain its tradition as a healing profession. In the process, physicians may discover meaningful connections with patients that bring new and refreshing perspectives to their work.
\end{abstract}

Ann Fam Med 2009;7:170-175. DOI: 10.1370/afm.943.

Also, I would like a doctor who is not only a talented physician, but a bit of a metaphysician, too. Someone who can treat body and soul.

Anatole Broyard ${ }^{1(\mathrm{p} 40) *}$

$\mathrm{D}$ uring 30 years of teaching family medicine residents, I have witnessed many changes in medicine and the image of physicians. As reflected by television, the warm and understanding Dr Marcus Welby (whose program debut was the year family medicine became a specialty) has morphed into the arrogant, cynical Dr Gregory House. Whereas Welby helped patients struggling with transformations in their lives through the strength of his humanity, House condescendingly rescues them from death by sagacity and technology. This evolution seems to mirror changes in medicine grown more technically sophisticated and powerful while physician morale has plummeted and public trust eroded. ${ }^{2-4}$ What happened?

Contemporary society has entered a postmodern era in which economic, philosophical, and technological advances have transformed medicine, doctoring, and the doctor-patient relationship. ${ }^{5} \mathrm{~A}$ growing service economy rendered physicians "providers," patients "customers," and medicine a "product." A belief in the relativity of knowledge categorizes biomedicine as but one of a variety of legitimate healing models that vie for patients. The authority of the patient's story of illness now competes with the doctor's story of disease. Doctors are confronted with medical information garnered from the Internet, often of dubious quality and unrelated to the patient's clinical condition. A colleague recently reported having a

* All quotes attributed to Broyard in this article are from: Intoxicatd by My illness by Anatole Broyard, copyright () 1992 by the Estate of Anatole Broyard: Used by permission of Clarkson Potter/Publishers, a division of Randome House, Inc. 
9-year-old patient request a hypnotic by brand name, thanks to television advertising. The world of contemporary doctoring has changed!

It seems today's physicians are expected to be an amalgam of Welby's warmth and House's brilliance. As advances in the prevention and treatment of acute disease mean more patients suffer longer with chronic diseases, the traditional medical goals of healing and the relief of suffering become more pressing. Thus, we have entered an era in which the many value questions that arise from and cannot be resolved by a purely curative approach to medicine beg consideration. ${ }^{6}$ Saving and prolonging life incur an obligation to accompany patients on their illness journeys, to care for their souls as well as their bodies. Yet, medical training hardly equips physicians to help patients with the metaphysical ramifications of their illnesses. ${ }^{7}$

This essay explores the thesis that contemporary physicians are challenged to both cure disease and to help patients holistically heal, to be physician-healers. It is written with the assumption that a greater appreciation of the nature of holistic healing may help physicians more effectively adapt to a changing world. As social and technical change influence medicine, issues of suffering, meaning, and healing are emerging as integral parts of the work of doctoring. Assuming the role of physician-healer may assist physicians caring for suffering patients, particularly the chronically ill, and may stimulate new meaning to their work.

To illustrate my points, I shall use the words of Anatole Broyard, who chronicled his experience of being doctored while dying of prostate cancer. ${ }^{1}$ An author, literary critic, and editor, Broyard astutely observed the human condition and captured his observations in vivid prose. An intellectual, hipster, and Bohemian writer ${ }^{8}$ who lived in Greenwich Village during the flowering of the Beat Generation, Broyard powerfully reflects the postmodern mentality that influences contemporary doctoring.

\section{SUFFERING, MEANING \& HEALING}

Holistic healing may be understood as "the personal experience of the transcendence of suffering." ${ }^{\text {"S }}$ Sufering is an intrinsically disagreeable experience that is angst of an order different than pain, though it may involve pain..$^{10}$ It arises from perceptions of impending destruction of an individual's personhood and continues until the threat of disintegration has passed or the integrity of the person is restored in some other manner. ${ }^{11}$ As such, suffering subsumes nonphysical dimensions-social, psychological, cultural, spiritual-associated with being a person that are relatively unaddressed in medical training. . $^{91,12}$
Suffering is personal, individual, and commonly expressed as a narrative..$^{13,14}$ "My initial experience of illness was as a series of disconnected shocks," Broyard reported, "and my first instinct was to try to bring it under control by turning it into a narrative. Always in emergencies we invent narratives." ${ }^{\text {"1 }}$ p19) Although sources of suffering may be shared in common-eg, the massive loss of life caused by the 2004 Indian Ocean tsunami-the particulars of suffering for any individual remain exclusively personal and anecdotal. The conventional expectation of narrative involving a past leading into a present that foretells a foreseeable future is "wrecked" by illness. ${ }^{15}$ The present is not what the past was supposed to foreshadow, and the future is too frightening to contemplate.

Because suffering arises from the meaning ascribed to events, it engenders a crisis of meaning ${ }^{16}$ as previous meanings attributed to the sufferer's experience no longer apply. ${ }^{17}$ The patient's suffering must be heard and accepted, as the denial of the patient's story of suffering and sacrifice is a denial of the patient's identity as a sufferer. ${ }^{18}$ "To the typical physician, my illness is a routine incident in his rounds," Broyard observed, "while for me it's the crisis of my life. I would feel better if I had a doctor who at least perceived this incongruity."1(p43) Suffering fills the chasm of meaninglessness that opens when the patient's previously held meaning structures have been destroyed and new ones are yet to be constructed. ${ }^{17}$ The physician-healer affirms the sense of meaninglessness conveyed in the patient's narrative and then helps the patient to create or discover a healing narrative with new meanings that transcend suffering. ${ }^{19}$

\section{TRANSCENDING SUFFERING}

Suffering may be resolved if the threat to integrity is removed, distress relieved, and integrity of personhood reconstituted to resume purposeful engagement with the world. Not all suffering can be resolved, and some types are beyond medicine. ${ }^{20,21}$ Still, suffering can be transcended through acceptance, through the creation of new connections with the world, and through finding meaning in the experience of suffering.

Transcendence means "extending or lying beyond

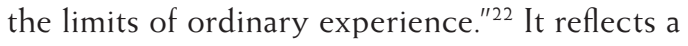
change in the patient's relationships to the illness, ${ }^{23}$ to others, and to the world that results in rising above the suffering previously experienced. It entails flowing with or adapting to changes from the patient's ordinary experience induced by life cycle events, disease, trauma, or degeneration. Transcendence is categorically different from being cured of disease, and cure does not equate to healing. Transcendence of suffering 
through holistic healing can occur regardless of cure, restoration of health, continued illness or impairment, or impending death. ${ }^{9}$

How does acceptance help patients transcend suffering? Intactness of personhood is forged through attachments to those aspects by which one identifies oneself as a person and defines one's sense of meaning and purpose in life. The severing of an attachment precipitates suffering as it disrupts the previous sense of personal integrity with its attendant senses of meaning. ${ }^{13,24}$ By accepting the change and neither pursuing nor rejecting the severed attachment, suffering is transcended. 25,26

Acceptance can be assisted by normalizing the patient's feelings and responses to illness. "It is only natural for a patient to feel some disgust at the change brought about in his body by illness," Broyard observed, "and I wonder whether an innovative doctor couldn't find a way to reconceptualize this situation."1(p48) The physician-healer helps the patient discover opportunities for growth in the most dire of circumstances, and the ability to transcend suffering exists even in the presence of the most frightening of diseases. For example, a substantial percentage of advanced cancer patients report little or no suffering, ${ }^{27}$ and there is ample witness to the peace evinced by persons who have accepted their impending deaths. ${ }^{28,29}$

For the suffering patient, acceptance often results in a personal style for handling the illness, as Broyard described: "...every seriously ill person needs to develop a style for his illness. I think that only by insisting on your style can you keep from falling out of love with yourself as the illness attempts to diminish or disfigure you."1(p25) This style reflects a new sense of identity. "You don't really know that you're ill until the doctor tells you so. When he tells you you're ill," wrote Broyard, "this is not the same as giving you permission to be ill. You eke out your illness. You'll always be an amateur in your illness." ${ }^{1(137)}$ A new sense of integrity, a new connection to the world and to others, a new way of being emerges.

Suffering is also transcended by investiture with meaning. Because suffering arises in a void of meaninglessness, discovering meaning transforms the experience. "Suffering ceases to be suffering in some way," Victor Frankl observed, "at the moment it finds a meaning." ${ }^{\prime 30}$ Thus, the extremely ill Pope John Paul II, unable to perform his Pontifical duties during Holy Week, announced he was "uniting his sufferings with those of Christ" ${ }^{\prime \prime 1}$ and invested his illness experience with a meaning that transcended his suffering. "Meaning," physician Jeff Kane has argued, "is as central to healing as the skeleton is to the body." ${ }^{23}$ Broyard concurred: "Any meaning of illness is better than none."1(p65)

\section{HEALING CONNECTIONS}

Sickness separates persons from wholeness with the world as known in health. "My friends flatter me by calling my performance courageous or gallant," wrote Broyard, "but my doctor should know better. He should be able to imagine the aloneness of the critically ill, a solitude as haunting as a Chirico painting."1(p42) To ameliorate isolation, the physicianhealer becomes a "therapeutic instrument," providing relationships to "reconnect sick persons to the world of the well." 32 Toward this end, continuity of caring relationships through time and the patient's feeling of being known are very important aspects of healing. 9,33

Therapeutic contact involves a therapeutic alliance facilitated by empathy, warmth, and genuineness. ${ }^{34}$ Being "heard and accepted" goes beyond an intellectual understanding of the sufferer's plight. It entails the development of a relationship that links the patient, at a minimum through the doctor-patient relationship, to a community that turns toward a new future despite the changes the patient has experienced.

Suchman and Matthews described the therapeutic relationship as having a "connexional," transpersonal dimension that bonds physician and patient in "a sensation of wholeness. ${ }^{35}$ "I wouldn't demand a lot of my doctor's time: I just wish he would brood on my situation for perhaps 5 minutes," Broyard proclaimed, "that he would give me his whole mind just once, be bonded with me for a brief space, survey my soul as well as my flesh, to get at my illness, for each man is ill in his own way." ${ }^{1(\mathrm{p} 44)}$ In connexion, both physician and patient are vulnerable to the risks intrinsic to transpersonal intimacy. ${ }^{33,36}$ "The sick man asks far too much," wrote Broyard, "he is impatient with everything, and his doctor may be afraid of making a fool of himself in trying to reply." ${ }^{\prime 1(\mathrm{p} 54)}$ Yet, sharing vulnerability opens the possibility of a healing connection around the commonality of human woundedness. ${ }^{37}$

The compassion that fosters a therapeutic alliance and enhances knowledge of another's suffering is aided by empathy, ${ }^{38}$ which requires a willingness to suffer some of the patient's pain in the sharing of suffering that is vital to healing. ${ }^{33,37,39,40}$ The empathic understanding that ensues from a strong therapeutic alliance allows physician-healers to actively and intentionally guide patients in rewriting their life narratives to affirm normalcy, establish acceptance, discover meaning, make new connections to the world, transcend suffering, and experience healing. ${ }^{9,36,41}$

Because healing is a process ${ }^{42}$ the metamorphosis of the role of doctor to healer is the change from doer to helper, ${ }^{43}$ from expert problem solver and fixer to servant and companion, an accompanier on the healing journey. 


\section{HEALING AND NARRATIVE}

The work of healing is often a work of narration, of eliciting the patient's illness story and then helping the patient discover a new, healing story. ${ }^{19}$ "Stories," claimed Broyard, "are antibodies against illness and pain." ${ }^{\prime 1(p 2)}$ This narrative work requires understanding the format of illness stories and knowing how to help patients edit their stories. Illness stories reflect descriptions of experiences of devastation, reflection, and response. They portray broad truths of the patient's experience of illness and life, are interpretable and invested with an emotional core, and must be told in the style of the teller. ${ }^{23}$

The physician-healer creates a safe environment for patients to reveal their stories by encouraging storytelling. ${ }^{19}$ Toward this end, physicians must belay intentions to heal and suspend personal views and values so they can enter the patient's world without bias. ${ }^{23,44}$ What the sick man wants most from people, according to Broyard, "is not love but an appreciative critical grasp of his situation, what is known now in the literature of illness as 'empathetic witnessing.' The patient is always on the brink of revelation, and he needs an amanuensis." ${ }^{\prime(p 44)}$ An amanuensis is an individual who can skillfully transcribe speech!

How are healing narratives developed? Ultimately, this work is the patient's, for it is the patient's healing. To help, physician-healers must be competent in narrative medicine. ${ }^{19,45}$ They must ground the medical story in the patient's experience ${ }^{46}$ which necessitates a patient-centered approach, ${ }^{47}$ and they must be curious about their patients' stories. Curiosity is best expressed through circular questions that directly address the patient's concerns and invite embellishment of the story. ${ }^{19}$ "Besides talking himself," Broyard observed, "the doctor ought to bleed the patient of talk, of the consciousness of his illness, as earlier physicians used to bleed their patients to let out heat or dangerous humors." ${ }^{\prime 1(\mathrm{p} 53)}$

Physician-healers also help patients cope with the impersonality of technology by connecting the patient's illness narrative with the technomedical story. "Since technology deprives me of the intimacy of my illness, makes it not mine but something that belongs to science," observed Broyard, "I wish my doctor could somehow repersonalize it for me." ${ }^{\text {"1(p47) }}$ Helping patients to make this connection, Broyard maintained, allows patients to better own their illnesses. The disease story must be connected with the illness narrative for a patient to create a healing narrative, a style for living with the illness. ${ }^{46}$

By drawing out the patient's experience, the connections made in ascribing meaning to their illnesses, physician-healers help patients move through the processes of devastation to reflection and on to a new narrative that increases the ability to respond to the changes wrought by the illness. All aspects of the medical encounter can be used to help patients towards healing. ${ }^{48}$ Consider the patient who, after years of progressive debilitation with negative workups, wept with joy when finally diagnosed with multiple sclerosis. "Now I know I'm not crazy," the patient cried. "Whether he wants to be or not, the doctor is a storyteller," maintained Broyard, "and he can turn our lives into good or bad stories, regardless of the diagnosis."1(p53)

\section{BACK TO THE FUTURE}

As medicine evolves in the postmodern era, the clinical skills needed to manage a growing population of chronically ill patients will become increasingly important. An acute care, subspecialty, curative model of service delivery is insufficient for the needs of the chronically ill. ${ }^{49}$ Healing requires continuity of relationships to nurture the intimacy that permits the exploration of the meaning of illness., ${ }^{9,33}$ Toward this end, the Future of Family Medicine's call for a "medical home" with "patient-centered care," and a "whole-person orientation $^{\prime \prime 0}$ is very appropriate-but only viable if staffed by physician-healers skilled in helping patients transcend suffering.

The physician-healer must know how to actively diagnose suffering and explore its origins if detected. Doing so involves (1) direct questioning, (2) appreciating the sounds and sights of suffering, (3) sensing the loss of connection with patients who have withdrawn into their suffering, and (4) empathic identification. ${ }^{38}$ The diagnosis of suffering is uniquely dependent upon the clinician's subjective experience, making physicianhealers "strange instruments."

To manage the shared vulnerability of the close interpersonal relationships of healing, physician-healers must be mindful so they can balance their personal responses to patients with their professional presentation. ${ }^{52}$ Not allowing their own feelings and views to cloud a clear appreciation of the patient's experience permits physician-healers to affirmatively witness the patient's suffering. ${ }^{53}$ By cultivating such personal insight, physicians can manage any countertransference that is potentially harmful to the healing milieu. ${ }^{54}$

The change from expert-doer to servant-accompanier requires that physicians attend to how they are with patients as much as what they do for them. ${ }^{48}$ Empathic connection is not simply a nice relational attribute it has physiologic impacts. ${ }^{55}$ The chronically ill and their families need remoralization, ${ }^{56}$ making the physician-healer a morale catalyst. Physician-healers both cure disease and heal the sick. They use science 
to treat disease but draw on themselves to explore the meaning patients append to their illness experience and to guide healing. As evidence-based medicine guru David Sackett observed: "The most powerful therapeutic tool you'll ever have is your own personality." ${ }^{157}$

Whether physicians can be healers in a postmodern era in which medicine is an industry with clinic volumes that curtail meaningful dialogue with patients is a concern. ${ }^{33,42,58}$ This is perhaps the greatest challenge for contemporary medicine and the central struggle for its soul: Is the heart of medicine to be centered upon holistic healing or upon the adept dispersal of biomedical services as a market commodity? A health care delivery system focused on holistic healing would undoubtedly be tooled differently than our current model. At a minimum, it would promote access to and continuity of care, provide for home visits, equitably reimburse spending time with (rather than doing things to) patients, and provide parity in funding for mental health issues.

Skeptics will note that nothing written here is new. This is true. Whether it is Hippocrates' hypothesis, "It is more important to know what sort of person has a disease than to know what sort of disease a person has ${ }^{159}$; or Osler's admonition, "Care more particularly for the individual patient than for the special features of the disease $\mathrm{e}^{\prime \prime 60}$; or Peabody's opinion, "The secret of the care of the patient is caring for the patient ${ }^{\prime \prime 61}$; or Remen's reflection, "The practice of medicine is a special kind of love,"62 the principle is the same: healing is stimulated through the medium of close, caring interpersonal relationships. So it has been; so it shall be.

Once, physicians had little to offer patients except the strength of their personalities. With the advent of biomedicine, personality gave way to science and technology. The success of biomedicine requires contemporary physicians to connect personally with patients to heal the illnesses their technology can so forcefully sustain. "Just as a mother ushers her child into the world," Broyard proclaimed, "so the doctor must usher the patient out of the world of the healthy and into whatever physical and mental purgatory awaits him. The doctor is the patient's only familiar in a foreign country."1(p55) To not accompany patients on their illness journeys is to abandon them in a foreign world of sickness.

Some physicians may feel overwhelmed by the idea of assuming a healer role when time and energy are already at a premium. But not every patient coming to the physician needs healing. Most will not be suffering, nor will all who suffer need healing. Many will heal spontaneously as the miracles of cure remove any threat to the patient and allow reconnection with life as previously known. But all patients will eventu- ally fail, and medicine's power to prolong suffering is immense, so all patients will eventually need a skilled physician-healer.

Finally, developing the role of physician-healer may not only better serve the chronically ill but may also stem the tide of physician burnout and restore a sense of awe and mystery to medicine by reinstating the personal power of the physician as a therapeutic agent. ${ }^{33}$ As Broyard surmised: "Not every patient can be saved, but his illness may be eased by the way the doctor responds to him-and in responding to him the doctor may save himself.... In learning to talk to his patients, the doctor may talk himself back into loving his work. He has little to lose and everything to gain by letting the sick man into his heart."1(p57)

To read or post commentaries in response to this article, see it online at http://www.annfammed.org/cgi/content/full/7/2/170.

Key words: Healing; physician-patient relations; stress, psychological; suffering

Submitted February 29, 2008; submitted, revised, July 18, 2008; accepted August 22, 2008.

\section{References}

1. Broyard A. Intoxicated by My Illness. New York, NY: Fawcett Columbine; 1992.

2. Steiger B. Survey results: doctors say morale is hurting. Physician Exec. 2006;32(6):6-15.

3. Crawshaw R. Diminished medical morale syndrome. A profession's impairment. J S C MedAssoc. 2000;96(7):304-309.

4. Mechanic D. Changing medical organization and the erosion of trust. Milbank Q. 1996;74(2):171-189.

5. Morris DB. How to speak postmodern. Medicine, illness, and cultural change. Hastings Cent Rep. 2000;30(6):7-16.

6. Veatch RM. Contemporary bioethics and the demise of modern medicine. In: Ormiston G, Sassower R, eds. Prescriptions: The Dissemination of Medical Authority. New York, NY: Greenwood Press; 1990:22-39.

7. Rich BA. Postmodern medicine: deconstructing the Hippocratic Oath. Forum Appl Res Public Policy. 1993;65(1):77-136.

8. Mitgang $\mathrm{H}$. Anatole Broyard, 70, book critic and editor at the Times, is dead. New York Times. 1990 Oct 12;Sect. A:26 (col 1-3).

9. Egnew TR. The meaning of healing: transcending suffering. Ann Fam Med. 2005;3(3):255-262.

10. Chapman CR, Gavrin J. Suffering and its relationship to pain. J Palliat Care. 1993;9(2):5-13.

11. Cassell EJ. The nature of suffering and the goals of medicine. $N$ Engl J Med. 1982;306(11):639-645.

12. Cassell EJ. The nature of suffering: physical, psychological, social, and spiritual aspects. In Starck PL, McGovern JP, eds. The Hidden Dimension of Illness: Human Suffering. New York, NY: NLN Publications; $1992: 1-10$.

13. Moerman DE. Physiology and symbols: the anthropological implications of the placebo effect. In: Romanucci-Ross L, Moerman D, Tancredi L, eds. The Anthropology of Medicine: From Culture to Method. South Hadley, MA: J. F. Bergin Publishers; 1983:156-167. 
14. Reich WT. Speaking of suffering: a moral account of compassion. Soundings. 1989;72(1):83-108.

15. Frank AW. The Wounded Storyteller. Chicago, IL: University of Chicago Press; 1995.

16. Barrett DA. Suffering and the process of transformation. J Pastoral Care. 1999;53(4):461-472.

17. Kahn DL, Steeves RH. An understanding of suffering grounded in clinical practice and research. In Ferrell BR, ed. Suffering. Sudbury, MA: Jones and Bartlett Publishers; 1996:3-27.

18. Amato JA. Victims and Values: A History and a Theory of Suffering New York, NY: Praeger Publishers; 1990.

19. Launer J. Narrative-Based Primary Care: A Practical Guide. Oxon, UK: Radcliffe Medical Press; 2002.

20. Buddhism. In: Hitchcock ST, Esposito JL, Tutu D, Tutu M, eds. Geography of Religion: Where God Lives, Where Pilgrims Walk. Washington, DC: National Geographic Society; 2004:132-197.

21. Fleischer TE. Suffering reclaimed: medicine according to Job. Perspect Biol Med. 1999;42(4):475-488.

22. Webster's New Collegiate Dictionary. Springfied MA: G \& C Merriam Company; 1979;1230.

23. Kane J. How to Heal: A Guide for Caregivers. New York, NY: Helios Press; 2003.

24. Kegan R. The Evolving Self. Cambridge, MA; Harvard University Press; 1982.

25. Mikulas WL. Four noble truths of Buddhism related to behavior therapy. Psychol Rec. 1978;28:59-67.

26. Hayes SC, Smith S. Get Out of Your Mind and Into Your Life: The New Acceptance and Commitment Therapy. Oakland, CA: New Harbinger Publications; 2005

27. Wilson KG, Chochinov HM, McPherson CJ, et al. Suffering with advanced cancer. J Clin Oncol. 2007;25(13):1691-1697

28. Albom M. Tuesdays With Morrie: An Old Man, A Young Man, and Life's Greatest Lessons. New York, NY: Doubleday; 1997.

29. Buchwald A. To Soon to Say Goodbye. New York, NY: Random House; 2006

30. Frankl VE. Man's Search for Meaning: An Introduction to Logotherapy. New York, NY: Pocket Books; 1984.

31. Pope says he's uniting his pain with Christ's, will miss services. The News Tribune. 2005;March 19;Sect. A:3(col. 1).

32. Cassell EJ. The Nature of Suffering and the Goals of Medicine. New York, NY: Oxford University Press; 1991.

33. Scott JG, Cohen D, DiCicco-Bloom B, Miller WL, Stange KC, Crabtree BF. Understanding healing relationships in primary care. Ann Fam Med. 2008;6(4):315-322.

34. Hubble MA, Duncan BL, Miller SC. The Heart \& Soul of Change: What Works in Therapy. Washington DC. American Psychological Association; 1999.

35. Suchman AL, Matthews DA. What makes the patient-doctor relationship therapeutic? Exploring the connexional dimension of medical care. Ann Intern Med. 1988;108(1):125-130.

36. Matthews DA, Suchman AL, Branch LT Jr. Making "connexions": enhancing the therapeutic potential of patient-clinician relationships. Ann Intern Med. 1993;118(12):973-977

37. Nouwen HJM. The Wounded Healer. New York, NY: Image Books; 1979.
38. Cassell EJ. Recognizing suffering. Hastings Cent Rep. 1991;21(3): 24-31.

39. Pellegrino ED. The healing relationship: the architectonics of clinica medicine. In: Shelp EA, ed. The Clinical Encounter: The Moral Fabric of the Physician-Patient Relationship. Dordrecht, Holland: D. Reidel Publishing; 1983:153-172.

40. Jackson SW. The listening healer in the history of psychological healing. Am J Psychiatry. 1992;149(12):1623-1632.

41. Farber SJ, Egnew TR, Herman-Bertsch JL. Defining effective clinician roles in end-of- life care. J Fam Pract. 2002;51(2):153-158.

42. Hsu C, Phillips WR, Sherman KJ, Hawkes R, Cherkin DC. Healing in primary care: a vision shared by patients, physicians, nurses, and clinical staff. Ann Fam Med. 2008;6(4):307-314

43. Hammerschlag CA. The Theft of the Spirit: A Journey to Spiritual Healing With Native Americans. New York, NY: Simon \& Schuster; 1993.

44. Rogers CR. A Way of Being. Boston, MA: Houghton Mifflin Company; 1980.

45. Charon R. Narrative Medicine: Honoring the Stories of Illness. New York, NY: Oxford University Press; 2006.

46. Hunter KM. Doctor's Stories. Princeton, NJ: Princeton University Press; 1991.

47. Stewart M, Brown JB, Weston WW, McWhinney IR, Freeman TR. Patient-Centered Medicine. Transforming the Clinical Method. Thousand Oaks, CA: Sage Publications; 1995.

48. Adler HM. The history of the present illness as treatment: who's listening, and why does it matter? J Am Board Fam Pract. 1997;10(1):28-35

49. Fox E. Predominance of the curative model of medical care. A residual problem. JAMA. 1997;278(9):761-763.

50. Martin JC, Avant RF, Bowman MA, et al. The future of family medicine: a collaborative project of the family medicine community. Ann Fam Med. 2004;2(Suppl 1):S3-S32.

51. Cassell EJ. Diagnosing suffering: a perspective. Ann Intern Med. 1999;131(7):531-534.

52. Epstein RM. Mindful practice. JAMA. 1999;282(9):833-839.

53. Dass R, Gorman P. How Can I Help? New York, NY: Alfred A Knopf; 1991

54. Marshall AA, Smith RC. Physicians' emotional reactions to patients: recognizing and managing countertransference. Am J Gastroenterol. $1995 ; 90(1): 4-8$

55. Adler HM. The sociophysiology of caring in the doctor-patient relationship. J Gen Intern Med. 2002;17(11):883-890.

56. Kleinman A. The Illness Narratives. New York, NY: Basic Books; 1988

57. Smith R. Thoughts for new medical students at a new medical school. BMJ. 2003;327(7429):1430-1433.

58. Rastegar DA. Health care becomes an industry. Ann Fam Med. 2004;2(1):79-83.

59. Xplore, Inc. [Web site]. http://www.brainyquote.com/quotes/ authors/h/hippocrates.html. Accessed: Jul 8, 2008.

60. Silverman ME, Murray TJ, Brayan CS, eds. The Quotable Osler. Philadelphia, PA: American College of Physicians; 2003

61. Peabody FW. The care of the patient. JAMA. 1927;88:877-882.

62. Remen NR. Kitchen Table Wisdom. New York, NY: Riverhead Books; 2006. 